\title{
Downsizing Proteins Without Losing Potency or Function
}

\author{
David P Fairlie, 2,3, Mei-Kwan Yau ${ }^{1,2}$, Johan K Hamidon ${ }^{1,2}$, Ranee Singh ${ }^{1}$, \\ Junxian Lim ${ }^{1,2}$, Jacky Y Suen ${ }^{1,2,3}$, Jessica A Rowley ${ }^{1,2}$, Rink-Jan Lohman ${ }^{1,2,3}$, \\ Martin J. Stoermer ${ }^{1}$, Abishek Iyer ${ }^{1,2,3}$, and Robert C Reid ${ }^{1,2,3}$ \\ ${ }^{I}$ Division of Chemistry and Structural Biology, Institute for Molecular Bioscience, Brisbane, Queensland, 4072, \\ Australia; ${ }^{2}$ Australian Research Council Centre of Excellence in Advanced Molecular Imaging, The University \\ of Queensland, Brisbane, Queensland, 4072, Australia; ${ }^{3}$ Centre for Inflammation and Disease Research, \\ Institute for Molecular Bioscience, Brisbane, Queensland, 4072, Australia
}

\section{Introduction}

Human complement protein C3a (Figure 1) is produced after activation of a complex network of plasma and membrane proteins that constitute the complement system, named for their combined capacity to complement antibody-mediated immune defense [1,2]. C3a itself is an inflammogen, probably best known for its ability to attract (chemotaxis) and degranulate certain immune cells which contain granules that release inflammatory stimuli like histamine, tryptase, heparin and other enzymes most commonly associated with allergies, asthma and acute inflammatory responses [3-8]. We have used this inflammatory protein, which is rapidly degraded in plasma, as a test case to downsize a protein to plasma-stable small molecules that mimic the potent and selective functions of the full length $\mathrm{C} 3 \mathrm{a}$ protein. Here we summarize the principle and effectiveness of this idea, which starts with a functionally important amino acid in $\mathrm{C} 3 \mathrm{a}$ and rationally grows it into functional surrogates for $\mathrm{C} 3 \mathrm{a}$. We compare activity profiles for the resulting peptidomimetics versus human $\mathrm{C} 3 \mathrm{a}$, all compounds binding to a specific $\mathrm{G}$ protein coupled receptor $(\mathrm{C} 3 \mathrm{aR})$ expressed on the plasma membrane surface of human immune and other cell types $[9,10]$.

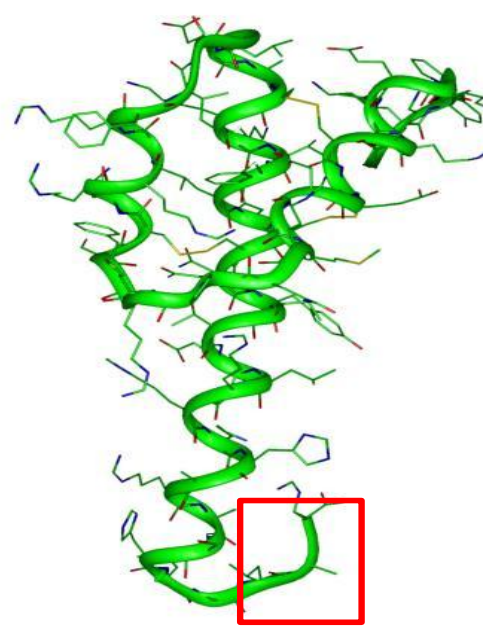

Fig. 1. Human C3a is 77 amino acids with its GPCR-activating $C$ terminus boxed.

\section{Results and Discussion}

The $C$-terminal arginine residue of $\mathrm{C} 3 \mathrm{a}$ has been reported to be important for binding to and activating human C3aR [11]. Receptor mutagenesis is consistent with $\mathrm{C} 3 \mathrm{a}$ interacting through its guanidinium side chain of Arg77 contacting Asp417 while its $C$-terminal carboxylate contacts Arg161 and Arg340 [12]. Moreover removal of this Arg77 residue from C3a dramatically reduces C3aR binding affinity and agonist efficacy. Our novel approach, inspired by our previous work with ascidiacyclamide and thiazole peptides [13-15], incorporates different dipeptide mimics (Figure 2) into the $C$-terminal tripeptide segment (Leu-Ala-Arg) of C3a, using a range of heterocycles as conformational constraints (Figure 3). These heterocyclic dipeptide mimics confer potent C3aR agonist or antagonist potencies.

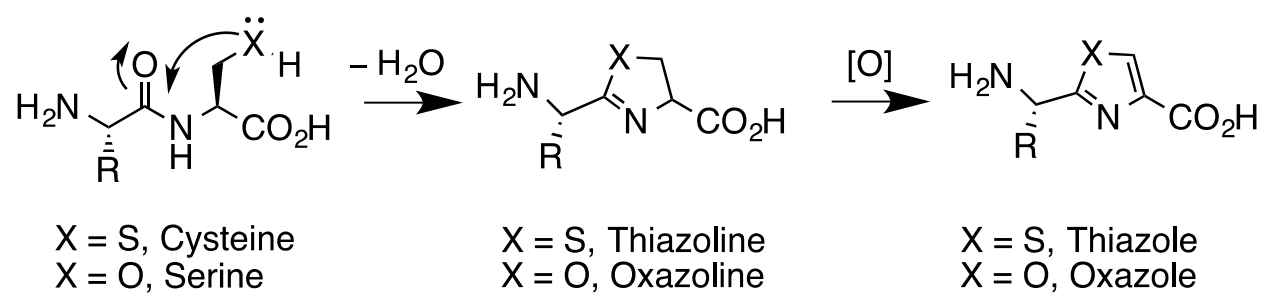

Fig. 2. Heterocyclic dipeptide mimetics derived from dipeptides. 
Boc-Leu-Ala-Arg

$\mathrm{EC}_{50}>10 \mathrm{mM}$<smiles>CC(C)C[C@H](NC(=O)OC(C)(C)C)c1nc(C(=O)N[C@@H](CCCNC(=N)N)C(=O)O)c[nH]1</smiles>

$\mathrm{EC}_{50} 0.12 \mu \mathrm{M}$<smiles>CC(C)C[C@H](NC(=O)OC(C)(C)C)c1nc(C(=O)N[C@@H](CCCNC(=N)N)C(=O)O)cn1C</smiles>

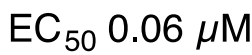<smiles>CC(C)C[C@H](NC(=O)OCc1ccccc1)c1ncc(C(=O)N[C@@H](CCCNC(=N)N)C(=O)O)n1C</smiles>

$\mathrm{EC}_{50} 9.4 \mu \mathrm{M}$<smiles>CC(C)C[C@H](NC(=O)OCc1ccccc1)c1nc(C(=O)N[C@@H](CCCNC(=N)N)C(=O)O)co1</smiles>

$\mathrm{EC}_{50} 0.06 \mu \mathrm{M}$<smiles>C[C@H](NC(=O)OCc1ccccc1)c1nc(C(=O)N[C@@H](CCCNC(=N)N)C(=O)O)co1</smiles>

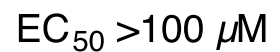<smiles>CC(C)C[C@H](NC(=O)c1c[nH]c2ccccc12)c1nc(C(=O)N[C@@H](CCCNC(=N)N)C(=O)O)co1</smiles>

$\mathrm{EC}_{50} 0.007 \mu \mathrm{M}$

Fig. 3. Agonist potency of peptidomimetics measured by $\mathrm{Ca}^{2+}$ release in human monocyte-derived macrophages relative to the tripeptide Boc-Leu-Ala-Arg and hC3a $\left(E C_{50} 40 \mathrm{nM}\right)$.

We found that the nature of the heterocycle profoundly affected compound activity. For example, a hydrogen-bond accepting nitrogen conferred agonist activity, with much greater potency for imidazoles and oxazoles (Figure 3 ) than for oxadiazoles, furans and other heterocycles. Interestingly, there was a linear correlation $[9,10]$ between the $\mathrm{C} 3 \mathrm{aR}$-binding affinity (measured by competition with ${ }^{125} \mathrm{I}-\mathrm{C} 3 \mathrm{a}$ ) and the calculated hydrogen-bond acceptor interaction energy ( $\mathrm{kcal} \mathrm{mol}^{-1}$ ) between water and heteroatom of heterocycles compared with the water dimer (determined using ab initio methods MP2/6-311++G(3d,3p) and corrected for the basis set superimposition error within Gaussian 09). This enabled us to tune agonist potency by rational variation of the heterocyclic component incorporated into the dipeptide mimetics, coupled with changes to other substituents. All of these compounds were far more stable in rat plasma (unchanged after $2 \mathrm{~h}$ ) than $\mathrm{C} 3 \mathrm{a}$ (undetectable after $10 \mathrm{mins}$ ), suggesting their use as agonist surrogates for $\mathrm{C} 3 \mathrm{a}$ in vitro and possibly in vivo.

However, the above information only relates to one functional measure of comparable agonist activity for these ligands compared to human $\mathrm{C} 3 \mathrm{a}$. The most potent agonists were therefore further examined for other agonist properties typically exhibited by human $\mathrm{C} 3 \mathrm{a}$. We found that the most potent small molecule agonists also displayed comparable profiles of agonist function and potency to human $\mathrm{C} 3 \mathrm{a}$ in other assays such as chemotaxis (migration), ERK phosphorylation, inflammatory gene expression (TNF, IL1 $\beta, I L 8, C C L 3, P T G S 2, I L 6, F O S B, E G R 1)$ in human macrophages; mast cell activation and degranulation; and neutrophil migration and activation. These and other activities gave us confidence to examine the agonists in many other in vitro and in vivo assays to stimulate the C3a receptor and anticipate that the responses would be similar to those of $\mathrm{C} 3 \mathrm{a}$, which is only maintained intact at or near the cell surface where it is formed during complement activation. 
However, when a thiazole was incorporated into these peptidomimetics there was an interesting finding of either agonist or antagonist activity, depending upon the location of the sulfur and nitrogen atoms relative to the adjacent amide carbonyl group (Figure 4). When the thiazole nitrogen was adjacent to the carbonyl, agonist activity was observed. When the thiazole sulfur was adjacent to the carbonyl the compound was instead an antagonist. The latter is attributed [16] to orbital interaction between the sulfur and oxygen, indicated by the distance between sulfur and oxygen being less than the sum of the van der Waals radii, and different $\delta+\ldots \delta$ - dipole alignments (Figure 4).

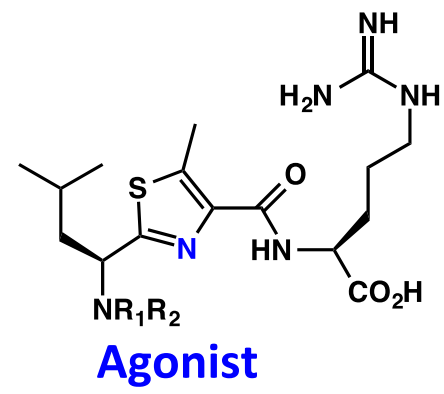<smiles>[R2]NC(=O)c1nc([R])[Y]([H])[nH]1</smiles>

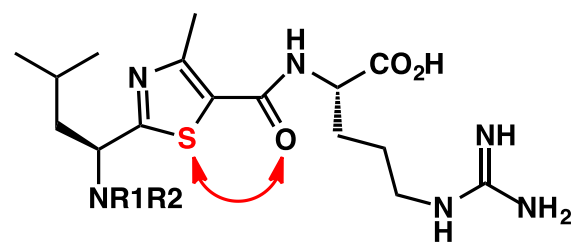

Antagonist<smiles>[R2]NC(=O)c1n[X]c([O-])s1</smiles>

Fig. 4. Heterocycle can control conformation of adjacent amide and hence projection of arginine, dictating agonist versus antagonist action.

As a consequence of these findings, we have been able to gain access to both potent agonists (e.g. Figure 3) and antagonists (e.g. Figure 5) which can be used to probe the effects of modulating the C3a receptor in a range of human and rodent cells and in animal models of C3aR-mediated inflammation and disease. Indications alluded to in the seminar are that antagonists are far more potent than the known feeble antagonist SB290157 [17], in macrophages, mast cells and neutrophils and in animal models such as the rat paw oedema induced by small stable $\mathrm{C} 3 \mathrm{aR}$ agonists. Oral delivery of C3aR antagonists $(5-20 \mathrm{mg} / \mathrm{kg}$ doses) to rats prior to intraplantar administration of C3aR agonist (350 $\mu \mathrm{g} / \mathrm{paw}$ ) was able to inhibit the resulting acute inflammation manifested by paw swelling, mast cell activation and degranulation at 30 mins, neutrophil infiltration and activation at $6 \mathrm{~h}$, and inflammatory gene and protein expression induced by $\mathrm{C} 3 \mathrm{aR}$ agonists in vivo.
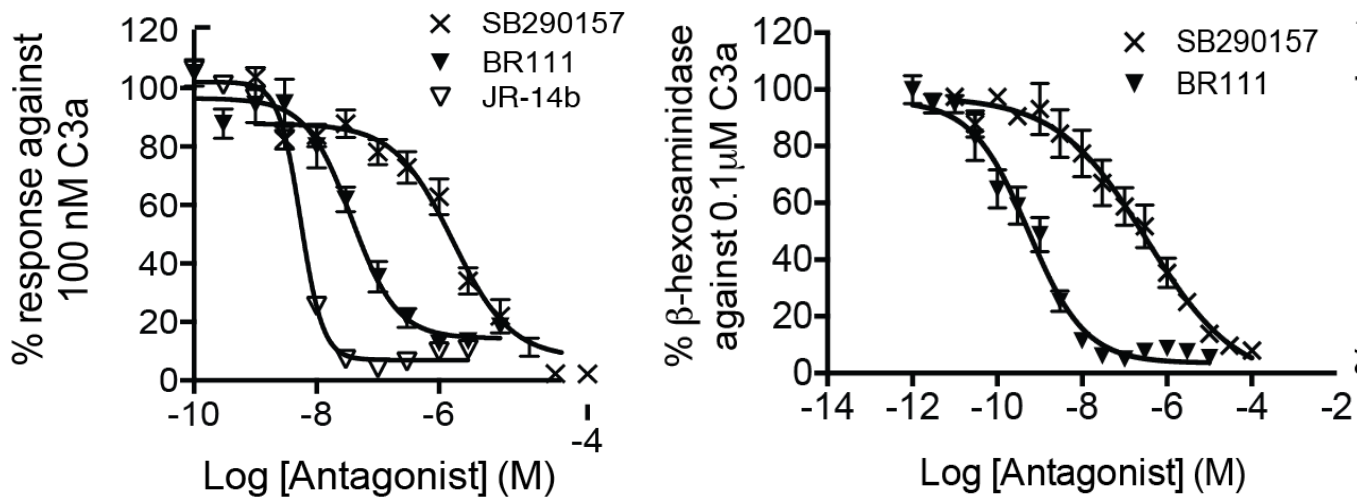

Fig. 5. Antagonism by heterocyclic peptidomimetics of C3a-induced (left): $\mathrm{Ca}^{2+}$ release in human monocyte-derived macrophages, (right): $\beta$-hexosaminidase release in LAD2 human mast cells. 


\section{Acknowledgments}

We thank the Australian Research Council for a grant (DP130100629), the Australian National Health and Medical Research Council for grants $(1028243,1030169,1084018)$ and for a Senior Principal Research Fellowship to DF (1027369). Enabling support is also gratefully acknowledged from the ARC Centre of Excellence in Advanced Molecular Imaging (CE140100011) and the Queensland State Government (CIF grant).

\section{References}

1. Ricklin, D., Hajishengallis, G., Yang, K., et al. Nature Immunol. 11, 785-797 (2010), http://dx.doi.org/10.1038/ni.1923

2. Klos, A., Wende, E., Wareham, K.J., Monk, P.N. Pharmacol. Rev. 65, 500-543 (2013), http://dx.doi.org/10.1124/pr.111.005223

3. Gerard, N.P., Gerard, C. Curr. Opin. Immunol. 14, 705-708 (2002), http://dx.doi.org/10.1016/S09527915(02)00410-7

4. Mizutani, N., Nabe, T., Yoshino, S. J. Immunol. 183, 4039-4046 (2009), http://dx.doi.org/10.4049/jimmunol.0901468

5. Zipfel, P.F., Skerka, C. Nat. Rev. Immunol. 9, 729-740 (2009), http://dx.doi.org/10.1038/nri2620

6. Hutamekalin, P., Takeda, K., Tani, M., Tsuga, Y., Ogawa, N., Mizutani, N., Yoshino, S. J. Pharmacol. Sci. 112, 56-63 (2010), http://dx.doi.org/10.1254/iphs.09180FP

7. Banda, N.K., Hyatt, S., et al. J. Immunol. 188,1469-1478 (2012), http://dx.doi.org/10.4049/jimmunol.1102310

8. Peng, Q., Li, K., Smyth, L.A., Xing, G., Wang, N., Meader, L., Lu, B., Sacks, S.H., Zhou, W. J. Am. Soc. Nephrol. 23, 1474-1485 (2012), http://dx.doi.org/10.1681/ASN.2011111072

9. Reid, R.C., Yau, M.K., Singh, R., Hamidon, J.K., Reed, A.N., Chu, P., Suen, J.Y., Stoermer, M.J., Blakeney, J.S., Lim, J., Faber, J.M., Fairlie, D.P. Nat. Commun. 4, 2802 (2013), http://dx.doi.org/10.1038/ncomms3802

10. Reid, R.C., Yau, M.K., Singh, R., Hamidon, J.K., Lim, J., Stoermer, M.J., Fairlie, D.P. J. Med. Chem. 57, 8459-8470 (2014), http://dx.doi.org/10.1021/jm500956p

11. Wilken, H.C., Gotze, O., Werfel, T., Zwirner, J. Immunol. Lett. 67, 141-145 (1999), http://dx.doi.org/10.1016/S0165-2478(99)00002-4

12. Sun, J., Ember, J.A., Chao, T.H., Fukuoka, Y., Ye, R.D., Hugli, T.E. Protein Sci. 8, 2304-2311 (1999), http://dx.doi.org/10.1110/ps.8.11.2304

13. Abbenante, G., Fairlie, D.P., Gahan, L.R., Hanson, G.R., Pierens, G., van den Brenk, A.L. J. Am. Chem. Soc. 118, 10384-10388 (1996), http://dx.doi.org/10.1021/ja962260f

14. Sokolenko, N., Abbenante, G., Scanlon, M.J., Jones, A., Gahan, L.R., Hanson, G.R., Fairlie, D.P. J. Am. Chem. Soc. 121, 2603-2604 (1999), http://dx.doi.org/10.1021/ja983354n

15. Singh, Y., Stoermer, M.J., Lucke, A., Guthrie, T., Fairlie, D.P. J. Am. Chem. Soc. 127, 6563-6572 (2005), http://dx.doi.org/10.1021/ja0455300

16. Reid, R.C., Yau, M., Singh, R., Lim, J., Fairlie, D.P. J. Am. Chem. Soc. 136, 11914-11917 (2014), http://dx.doi.org/10.1021/ja506518t

17. Ames, R.S., et al. J. Immunol. 166, 6341-6348 (2001), http://dx.doi.org/10.4049/jimmunol.166.10.6341 